\title{
EQUINE TRACHEOBRONCHIAL WASH FILTRATION AND ITS EFFECTS ON DIFFERENTIAL CELL COUNT
}

\section{EFEITO DA FILTRAÇÃO DO LAVADO TRAQUEOBRÔNQUICO DE EQUINOS SOBRE A CONTAGEM DIFERENCIAL DE CÉLULAS}

\author{
Nathalia Fontes de Souto dos Santos ${ }^{1^{*}}$ \\ Vanessa Viscardi2 \\ Anna Clara Porthun Caruso ${ }^{1}$ \\ Rodolpho de Almeida Torres Filho ${ }^{1}$ \\ Nayro Xavier de Alencar ${ }^{1}$ \\ Daniel Augusto Barroso Lessa ${ }^{1}$ \\ 1 Universidade Federal Fluminense, Niterói, RJ, Brasil \\ 2 Polícia Militar do Rio de Janeiro, Rio de Janeiro, RJ, Brasil \\ *Autora para correspondência - nathaliafontess@gmail.com
}

\begin{abstract}
Tracheobronchial wash (TBW) is a method to recover cell samples from the airways. The cytology of TBW fluid is an important technique for the diagnosis of pulmonary diseases in horses. Excessive mucus in TBW may cause cell damage and morphological changes that hinder cell type recognition, resulting in a misdiagnosis. The aim of this study was to compare the results of differential cell count in a tracheobronchial wash of filtered and non-filtered samples. Endoscopy and TBW procedures were performed in thirty horses. Each TBW sample was split into two aliquots. Two groups were formed: non-filtrated aliquots (NF) and filtrated aliquots (F). The filtration was performed using a hydrophilic gauze pad. After centrifugation, the differential cell count was performed considering 300 nucleated cells. The filtrated aliquots results presented a significant increase of macrophages count and a significant decrease in neutrophils count comparing to the results of non-filtrated aliquots. These findings were consistent with results of filtered bronchoalveolar wash published studies. Therefore, the filtration of TBW is not an efficient method.
\end{abstract}

Keywords: cytology; horses; tracheobronchial wash.

\section{Resumo}

O lavado traqueobrônquico (LTB) é um método usado para recuperar uma amostra de células das vias respiratórias. A citologia do LTB é descrita como uma importante ferramenta no diagnóstico de doença pulmonar em equinos. O excesso de muco geralmente presente no LTB pode alterar a morfologia, dificultando a identificação dos tipos celulares e, por consequência, prejudicando a contagem diferencial de células e a interpretação diagnóstica. O objetivo deste trabalho foi verificar o efeito da filtração do LTB de equinos sobre a contagem diferencial de células na avaliação citológica do lavado traqueobrônquico. Foram utilizados 30 equinos que foram submetidos a coletas de amostras de LTB via endoscópio. De cada amostra obtida foi separada uma primeira alíquota não filtrada (NF). Uma segunda alíquota (F) foi obtida filtrando-se o LTB, utilizando-se uma compressa de gaze hidrófila. As alíquotas $\mathrm{F}$ e NF foram submetidas à citocentrifugação para contagem diferencial de 
300 células nucleadas. Verificou-se um aumento significativo no percentual de macrófagos e redução significativa de neutrófilos nas amostras filtradas. As alterações observadas foram condizentes com achados de estudos prévios realizados em lavado broncoalveolar. Conclui-se que a filtração do LTB não é uma metodologia aconselhável, pois acarreta em alterações de contagem significativas nas proporções de importantes marcadores celulares de inflamação, podendo gerar possíveis erros de diagnóstico.

Palavras-chave: cavalos; citologia; lavado traqueobrônquico.

Enviado em: 7 outubro de 2014

Aceito em: 15 setembro de 2015

\section{Introduction}

Horse health and athletic performance depend on the proper functioning of the respiratory system. Respiratory diseases may cause significant economic losses to equine industry worldwide ${ }^{(1)}$. Horses present high prevalence of inflammatory lung diseases, which may be associated with environmental management and work conditions ${ }^{(2)}$.

The study of samples of the respiratory tract fluid has been considered extremely useful as an important technique for diagnosis of pulmonary diseases in horses ${ }^{(3,4)}$, and it is often performed in Brazil ${ }^{(5-12)}$. The interpretation of cytological findings may vary depending on sampling and processing techniques ${ }^{(13)}$. The tracheobronchial aspiration technique has been used for a long time, and it was introduced in equine medicine in $1975^{(14)}$. Later, the aspiration sampling technique via endoscopy was described ${ }^{(15)}$. In 2003, researchers asserted that this method had become popular, and it has been considered a real alternative to sample tracheal fluids ${ }^{(16)}$.

The cytological preparation for differential cell count can be performed by cytospin or by making smears from sediment obtained in conventional centrifugation ${ }^{(3)}$. However, excessive mucus in the tracheobronchial wash (TBW) may cause cell morphological changes that hinder cell type recognition resulting in a misdiagnosis.

The filtration of bronchoalveolar lavage (BAL) fluid should be performed through two hydrophilic gauze pads to remove excessive mucus and other debris before performing the counting ${ }^{(17)}$. However, the filtration process may cause a selective loss of several cell types in BAL ${ }^{(13,18,19)}$ and tracheal aspirate fluid $^{(13)}$. Currently, there are no published studies related to TBW filtration. The aim of this study was to verify the effect of filtration of equine TBW on differential cell count.

\section{Materials and Methods}

The present study was performed following the Ethical Principles in Animal Experimentation, obtaining the approval of the Animal Research Ethics Committee (CEPA / UFF), under No. 00124/11. Tracheobronchial wash samples were collected via endoscopy from 30 crossbred, mature horses (25 males, five females), regularly dewormed and vaccinated, belonging to the Mounted Police Unit, Coronel Cony Enyr dos Santos (RPMont / CECS) from Rio de Janeiro, Brazil.

To perform the procedure, the horses were physically restrained with a nose twitch and were kept in stocks. The endoscope (Olympus ${ }^{\circledR}$ Colonofiberscope CF-10L) was introduced into the ventral meatus of the right or left nostril, randomly, and it was led to the bronchial bifurcation to obtain the TBW. The catheter (Guttural Pouch Catheter Flushing Endoscopy, SURGIVET ${ }^{\circledR}$ ) was introduced through the working channel of the endoscope and positioned in the distal portion of the trachea ${ }^{(20)}$. Then, $20 \mathrm{~mL}$ to $40 \mathrm{~mL}$ of sterile saline was instilled and immediately aspirated. Thus, the TBWs obtained were considered adequate when one or more of the following features were observed in the aspirated material: turbidity, suspended particles, strands of mucus.

The TBW samples were aspirated then transferred to $50 \mathrm{~mL}$ conical tubes, and kept under refrigeration 
until the time of processing, not exceeding four hours after collection. Two groups were formed: non-filtered aliquots (NF) and filtered aliquots (F). From each sample obtained the first non-filtered aliquot (NF) was separated and the second aliquot was filtered using an 8-layers hydrophilic gauze pad $\left(7.5 \mathrm{~cm} \times 7.5 \mathrm{~cm}, 13\right.$ yarns $\left./ \mathrm{cm}^{2}\right)$, obtaining the filtered aliquot $(\mathrm{F})$. For the cytological preparation, $200 \mu \mathrm{L}$ aliquots of TBW filtered (F) and non-filtered (NF) were subjected to cytospin (2400 Serocito, Fanem $\left({ }^{\circledR}\right)$ at $110 \mathrm{xg}$ for five minutes.

Finally, the filtered and non-filtered specimens were made and fixed in methanol and stained with Giemsa. Cytological analyzes were conducted with an optical microscope (OLYMPUS $₫$ CX 40) with an oil immersion (1000x) to the differential counting of 300 cells.

Based on reference values ${ }^{(21)}$ for TBW differential cell count (mean + s.d., $\%$ ), two samples of NF TBW were considered within normal limits (neutrophils $\leq 9.3+4.9 \%$ and eosinophils $\leq 0.2 \pm 0.6$ ), and 28 samples presented airway inflammation (neutrophils $>9.3+4.9 \%$ and/or eosinophils $>0.2 \pm$ $0.6)$.

To verify the effect of filtration on differential cell count, the statistical method of peer comparison with Microsoft Office Excel ${ }^{\circledR}$ was used, considering a significance level of 5\%.

\section{Results and Discussion}

Table 1 shows the result of the average differential count of tracheobronchial cytology of 30 equines used in this study, indicating a significant difference $(p<0.05)$ between the filtered and non-filtered samples only for macrophages and neutrophils. An increase in macrophages and decrease in neutrophils was observed in filtered samples. This outcome could be explained based on the fact that a rise in one type of cell generates a proportional reduction in the other or vice versa. Similarly, researchers observed that the reduction of epithelial cells caused a proportional increase of alveolar macrophages $^{(13)}$.

Table 1: Average and standard deviation of the differential cell count of cytology of tracheobronchial non-filtered (NF) and filtered (F) samples of 30 horses (in percentage)

Rio de Janeiro, 2010-2012

\begin{tabular}{l|llllll}
\hline Type & Epithelial cell & Macrophage & Lymphocyte Neutrophil & Eosinophil & Mast cell \\
\hline $\mathrm{NF}(\%)$ & $27.76+17.62$ & $28.56+11.92 *$ & $3.71+4.54$ & $38.00+23.67 *$ & $1.98+3.34$ & $0.00+0.00$ \\
\hline $\mathrm{F}(\%)$ & $27.64+16.34$ & $30.97+13.94 *$ & $3.57+4.66$ & $34.14+22.88 *$ & $2.57+4.69$ & $0.00+0.00$ \\
\hline
\end{tabular}

$\mathrm{NF}=$ Non-filtered sample; $\mathrm{F}=$ Filtered sample; * Significant difference $(\mathrm{p}<0.05)$.

The reduction in total nucleated cell count and selective loss of certain cell types were described by other researchers as a consequence of BAL filtration ${ }^{(13)}$. For example, BAL filtration resulted in the reduction of the number of macrophages as well as epithelial cells ${ }^{(13)}$, macrophage and mast cells $^{(13,22)}$, and increased neutrophil and lymphocyte ${ }^{(18)}$. In the present study, a percentage increase in macrophages and reduction in neutrophils were observed. These findings may have been caused by mucus and neutrophils retention on gauze.

The volume of fluid infused and retrieved may significantly influence cell counts, and the presence of abundant mucus may promote cell trapping that may alter the number of cells available for counting ${ }^{(23)}$. Once a smaller volume is used in TBW than in BAL (20-40 mL versus 300 a $500 \mathrm{~mL}$ ), and the amount of mucus is higher than in BAL, the cell trapping seems to be a major feature that causes a change of cell count. Thus, animals with mild pulmonary inflammatory conditions and discreet neutrophilic infiltrate on TBW cytology may have false negative results if the fluid has been filtered. 


\section{Conclusion}

The tracheobronchial wash filtration is not a recommended method. It results in significant changes in the count of cellular inflammatory markers, such as macrophages and neutrophils. Therefore, the filtration may cause misdiagnosis.

\section{References}

1. Hodgson JL, Hodgson DR. Inflammatory Airway Disease. In: LEKEUX, P. Equine Respiratory Diseases. Ithaca: International Veterinary Information Service. [Internet]. 2002. [cited 2012 Oct 19]. Available from: http://www.ivis.org/special_books/Lekeux/viel/chapter_frm.asp?LA=1

2. Van Erck E. Sampling the respiratory tract: techniques and interpretation. In: Congress on Equine Medicine and Surgery, 11th, Genève, Suisse. Proceedings. Ithaca: International Veterinary Information Service, 2009, 45-47 [Internet]. [cited 2012 Oct 19].Available from: http://www.ivis.org/proceedings/ geneva/2009/7.pdf

3. Hoffman AM. Bronchoalveolar Lavage: Sampling Technique and Guidelines for Cytologic Preparation and Interpretation .Veterinary Clinics of North America: Equine Practice. 2008;(24):2:423-435. Available from: http://dx.doi.org/10.1016/j.cveq.2008.04.003

4. Lessa DAB, Viana EB, Fernandes WR, Mori E, Moreira JFE. Lavado broncoalveolar em eqüinos: revisão de literatura - Parte 2: Achados citológicos. Arquivos de Ciências Veterinárias e Zoologia da Unipar. 2007;(10):31-38. Avaiable from: http://revistas.unipar.br/veterinaria/article/view/570/498

5. Dzyekanski B, Almeida SRP, Rocha DCC, Lopes ACAM, Pimpao CT, Villanova Junior JA, Michelotto JR PV. Resultados do uso associado dos lavados traqueal e broncoalveolar no diagnóstico das doenças respiratórias dos cavalos. Revista Acadêmica: Ciências Agrárias e Ambientais (PUCPR. Impresso). 2013;(11):359-365. Available from: file:///C:/Users/Laboratorio\%20Info/Downloads/academica-12673.pdf

6. Hugedus RM, Michima LES, Souza VRC, Dutra GHP, Fernandes WR, Coellho CS. Evaluation of tracheal wash of horses with exercise induced pulmonary hemorrhage trated with furosemide. Arquivo Brasileiro de Medicina Veterinária e Zootecnia. 2007;(59):527-529. Available from: http://dx.doi.org/10.1590/S010209352007000200040

7. Jorge MLLA, Viscardi V, Silva K M, Alencar NX, Torres Filho, RA, Lessa DAB. Atividade da fosfatase alcalina no lavado broncoalveolar de equinos de policiamento montado no Estado do Rio de Janeiro. Ciência Rural. 2014;(44): 92-96. Available from: http://dx.doi.org/10.1590/S0103-84782014000100015

8. Lessa DAB, Jorge MLLA, Lima JRPA, Fernandes WR. Doença inflamatória das vias aéreas (DIVA) em equinos de policiamento na cidade do Rio de Janeiro: Estudo Clínico. Revista Brasileira de Ciência Veterinária. 2008;(15):88-93. Available from: http://www.uff.br/rbcv/ojs/index.php/rbcv/article/ viewFile/396/221

9. Michelotto JR PV, Lessa DAB, Silva KM, Gawlowski, KRS, Fernandes WR. The airway fluid analysis - methods and interpretation for the athletic horse. Revista Brasileira de Ciência Veterinária (Impresso). 2013;(20):1-5. Available from: http://www.uff.br/rbcv/ojs/index.php/rbcv/article/view/99

10. Sad EP, Viscardi V, Costa MFM, Alencar NX, Hess TM, Lessa DAB. Cytology profile and age influence in the equine bronchoalveolar lavage in healthy and asymptomatic inflammatory airway disease. Ciência Rural. UFSM, Santa Maria, RS. 2013;(43):452-455. Available from: http://dx.doi.org/10.1590/S010384782013005000009 
11. Silva KM, Otaka JNP, Jorge MLLA, Gonçalves CAP, Alencar NX, Lessa DAB. Escore de hemossiderina em citologia de lavados traqueais para avaliação da hemorragia pulmonar induzida por esforço em cavalos de pólo após o exercício. Archives of Veterinary Science, Ed. Universidade Federal do Paraná. 2012;(17):40-45. Available from: http://ojs.c3sl.ufpr.br/ojs/index.php/veterinary/article/view/24805

12. Viscardi V, Alencar NX, Santos OJ, Fonseca ABM, Azevedo CAP, Assis Brasil LC, Lessa DAB.

Detecção da Antracose Pulmonar por meio do Lavado Broncoalveolar em Equinos Sadios e Portadores da Doença Inflamatória das Vias Aéreas (DIVA). Revista Universidade Rural, Série Ciências da Vida. EDUR, Seropédica, RJ. 2010;(30):133:140. Available from: http://www.editora.ufrrj.br/rcv2/vida_30_1/09v03.pdf

13. Hewson J, Viel L. Sampling, Microbiology and Cytology of the Respiratory Tract. In: LEKEUX, P. Equine Respiratory Diseases. Ithaca: International Veterinary Information Service.[Internet]. 2002. [cited 2012 Aug 10]. Available from: http://www.ivis.org/special_books/lekeux/viel/ivis.pdf

14. Beech J. Cytology of tracheobronchial aspirates in horses. Veterinary Pathology. 1975;12:157-164. Available from: http://dx.doi.org/10.1177/030098587501200301

15. Greet TR. Collection of tracheal aspirates in horses. In Practice. 1982;(4):5:148. Available from: http:// dx.doi.org/10.1136/inpract.4.5.148

16. Hodgson JL, Hodgson DR. Tracheal aspirates, indications, technique and interpretation. In: ROBINSON, N.E. Current Therapy in Equine Medicine 5. St. Louis (MO): Saunders,editors; 2003. 401-406p. Available from: http://www.sciencedirect.com/science/article/pii/B9780721695402501304

17. Willcox M, Kervitsky A, Watters LC, King Jr TE. Quantification of cells recovered by bronchoalveolar lavage: Comparison of cytocentrifuge preparations with the filter method. American Review of Respiratory Disease.1988;(138):74-80. Available from: http://dx.doi.org/10.1164/ajrccm/138.1.74

18. Kelly C, Ward C, Bird G, Hendrick D, Walters H. The Effect of Filtration on Absolute and Differential Cell Counts in Fluid Obtained at Bronchoalveolar Lavage. Respiratory Medicine. 1989;(83):2:107. Available from: http://dx.doi.org/10.1016/S0954-6111(89)80223-9.

19. Lam S, Richie JC, Kijek K. Effect of filtration and concentration on the composition of bronchoalveolar lavage fluid. Chest. 1985;(87):6:740-742. Available from: http://journal.publications.chestnet.org/data/ Journals/CHEST/21473/740.pdf

20. Whitwell KE, Greet TRC. Collection and evaluation of tracheobronchial washes in the horse. Equine Veterinary Journal, Henderson Group One editors. 1984;(16):499-508. Available from: http://dx.doi. org/10.1111/j.2042-3306.1984.tb02000.x

21.Richard, E.A., Fortier, G.D., Lekeux, P.M. and Van Erck, E. (2010) Laboratory findings in respiratory fluids of the poorly-performing horse. Vet. J. 185, 115-122. Available from: http://dx.doi.org/10.1016/j. tvj1.2009.05.003

22. Nicholls R, Pirie RS. Filtration of bronchoalveolar lavage fluid results in the selective loss of cells. In: World Equine Airways Symposium, 2nd, Edinburg, Scotland. Proceedings. Ithaca: International Veterinary Information Service 80-81. [Internet]. 2001. [Cited 2013 Jun 09]. Available from: http://www.ivis.org/ proceedings/WEAS/2001/toc.asp

23. Cian F; Monti P; Durham A. Cytology of the lower respiratory tract in horses: An updated review. Equine Veterinary. 2015. Available from: http://dx.doi.org/10.1111/eve.12376 